\title{
PENDIDIKAN KARAKTER PADA TAMAN KANAK KANAK KENAPA TIDAK ?
}

\begin{abstract}
ABSTRAK
Pendidikan karakter di Taman Kanak-kanak merupakan kelanjutan dari pendidikan karakter yang diselenggarakan di dalam keluarga. Pendidikan karakter pada Taman Kanak-kanak dapat dilakukan dengan cara pembisaan yang tidak tertulis namun dilangsungkan secara konsisten. Hal ini berarti kehidupan anak/ siswa dijiwai oleh internalisasi nilai nilai pendidikan karakter. Taman Kanakkanak dapat memainkan fungsi menggali dan menguatkan potensi, minat dan bakat yang dimiliki anak/siswa. Apalagi dalam kegiatan belajar mengajar di Taman Kanak-kanak pengembangan siswa diorientasikan kepada pengembangan dan pengeksplorasian potensinya. Dalam hal ini wawasan pendidikan karakter sudah tertanam mulai dalam keluarga, taman kanak-kanak dan akan berlanjut pada jenjang pendidikan selanjutnya. Kegiatan pembelajaran sehari hari di Taman Kanak-kanak dalam rangka pengembangan kemampuan kecerdasan yang tentu saja disesuaikan dengan prinsip prinsip pembelajarannya, serta nilai nilai yang dikembangkan dalam rangka pendidikan karakter.
\end{abstract}

Ening Widaningsih ${ }^{1}$

\section{Kata Kunci: Anak Usia Dini, Pendidikan Karakter, Taman Kanak-kanak}

\section{A. PENDAHULUAN}

Pendidikan secara filosofis merupakan upaya memanusiakan manusia dalam arti melalui pendidikan membentuk manusia yang baik. Dalam UU Sisdiknas Tahun 2003, bertujuan agar pendidikan tidak hanya membentuk insan Indonesia yang cerdas, namun juga berkepribadian atau berkarakter. Pendidikan menjadi sebuah solusi yang tepat ketika terjadi suatu fenomena yang menyimpang dalam kehidupan. Menurut Direktur Jenderal Manajemen Pendidikan Dasar dan Menengah (Mandikdasmen) Prof. Suyanto, Ph. D. bahwa karakter bangsa yang dimiliki sebagian masyarakat Indonesia saat ini dalam kondisi yang lemah; Merebaknya fenomena tersebut Menteri Pendidikan Nasional (Mendiknas) Mohamad Nuh sebagai fenomena sirkusitas lebih lanjut Mendikanas menjelaskan "fenomena sirkusitas merupakan gejala tercabutnya karakter asli masyarakat sehingga tercipta animali yang bersifat ironis-paradoksal dan sudah menjadi fenomena keseharian. Fenomena semacam ini dikhawatirkan pada akhirnya dapat menyebabkan terjadinya metamorfosis karakter bangsa”.Lebih lanjut Mendiknas saat menyampaikan amanah pada upacara peringatan Hardiknas, Minggu (02/05 2012) “ Kadang menjadi lucu dan mengherankan. Penegak hukum yang seharusnya menegakan hukum ternyata harus dihukum. Para pendidik yang mestinya mendidik, malah harus dididik. Para pejabat yang mestinya melayani masyarakat malah minta dilayani”. Masih dari Mendiknas menegaskan dengan bercermin pada kasus tersebut, pendidikan karakter menjadi hal yang sangat penting dan mendasar dalam upaya membangun karakter bangsa yang mulia.

\footnotetext{
${ }^{1}$ Dosen PGPUD UPI Kampus Cibiru
} 
Pendidikan karakter sebagai salah satu alternatif pendidikan hendaknya dapat dilaksanakan dimulai dari keluarga, Taman Kanak-kanak, Pendidikan Dasar, Pendidikan Menengah sampai Pendidikan Tinggi.

Dari kajian beberapa buku penulis mencoba menguraikan istilah karakter sebagai berikut: Istilah karakter baru dipakai secara khusus dalam konteks pendidikan pada akhir abad ke 18. Pencetusnya adalah FW Foerster terminalogi ini mengacu pada sebuah pendekatan analis - spiritualis dalam pendidikan, yang juga dikenal dengan teori pendidikan normatif. Lahirnya pendidikan karakter merupakan usaha untuk menghidupkan kembali pedagogi ideal spiritual yang sempat diterjang gelombang positivism yang dipelopori oleh filsuf Prancis Auguste Comre. Kamus bahasa Indonesia karakter berarti sifat-sifat kejiwaan, akhlak, tabiat dan watak. Sehingga dapat dikemukakan bahwa karakter anak yang diharapkan memiliki kualitas mental atau kekuatan moral, akhlak atau budi pekerti yang merupakan kepribadian khusus yang harus melekat kepada anakanak bangsa ini. M.Furqon Hidayatulah mengutip pendapat dari Rutland (2009) yang mengemukakan bahwa "karakter" berasal dari kata bahasa Latin yang berarti “dipahat”. Secara harfiah karakter artinya adalah kualitas mental atau moral, kekuatan moral, nama atau reputasinya. Hermawan Kertajaya mengemukakan bahwa karakter adalah ciri khas yang dimiliki oleh sesuatu benda atau individu. Ciri khas tersebut adalah asli dan mengakar pada kepribadian benda atau individu tersebut. (Jamal Ma'mur Asmani 2012). Selanjutnya melalui kajian buku-buku lainnya penulis mencoba menguraikan pengertian pendidikan karakter lainnya, dengan dua pemahaman dasar tentang: Pendidikan dan Karakter, Doni (2007 pada Zainal Akib: 2011) karakter bersifat subyektif, sebab berkaitan dengan struktur antropologis manusia dan tindakannya dalam memaknai kebebasannya sehingga mampu mengukuhkan keunikannya ketika berhadapan dengan orang lain. Sementara pendidikan senantiasa berkaitan dengan dimensi sosialitas manusia. Manusia sejak pertama kali dilahirkan membutuhkan kehadiran orang lain dalam menopang hidupnya. Oleh karena itu pendidikan karakter merupakan keseluruhan dinamika rasional antar pribadi dengan berbagai macam dimensi baik, dari dalam maupun dari luar. Agar pribadi itu semakin dapat menghayati kebebasannya sehingga ia dapat semakin bertanggungjawab atas pertumbuhan dirinya sendiri sebagai pribadi dan perkembangan orang lain dalam hidup mereka. Secara singkat pendidikan karakter bisa diartikan sebagai sebuah bantuan sosial agar individu itu dapat tumbuh dengan cara menghayati kebebasannya ketika hidup bersama dengan orang lain dalam dunia. Menurut Suyanto pada Zainal Aqib (2011) pendidikan karakter adalah pendidikan budi pekerti plus, yaitu melibatkan aspek pengetahuan (cognitive), perasaan (feeling), dan tindakan (action).

Pembentukan karakter merupakan salah satu tujuan pendidikan nasional. Pasal I UU SISDIKNAS Tahun 2003 menyatakan bahwa diantara tujuan pendidikan nasional adalah mengembangkan potensi peserta didik untuk memiliki kecerdasan, kepribadian dan akhlak mulia. Amanah UU SISDIKNAS tahun 2003 tersebut bermaksud agar pendidikan tidak hanya membentuk insan Indonesia yang cerdas, namun juga berkepribadian atau berkarakter. Sehingga lahir generasi bangsa yang tumbuh berkembang dengan karakter yang bernapas nilai nilai luhur bangsa serta agama. Pendidikan yang bertujuan melahirkan insan cerdas dan 
berkarakter kuat itu juga pernah ditegaskan oleh Martin Luther King: “ Intelligense plus character, that is the goal of true education" (Kecerdasan yang berkarakter adalah tujuan akhir pendidikan yang sebenarnya.) pada Doni Koesoema A. (2010).

\section{B. Hakikat Pendidikan Karakter}

Pendidikan karakter memiliki makna lebih tinggi dari pendidikan moral, karena pendidikan karakter tidak hanya berkaitan dengan masalah benar salah, tetapi bagaimana menanamkan kebiasaan (habit) tentang hal hal yang baik dalam kehidupan, sehingga anak /peserta didik memiliki kesadaran dan pemahaman yang tinggi, serta kepedulian dan komitmen untuk menerapkan kebajikan dalam kehidupan sehari hari. (E. Mulyasa pada Manajemen Pendidikan Karakter: 2012) lebih lanjut E. Mulyasa mengemukakan dalam konteks pemikiran Islam karakter berkaitan dengan iman dan ikhsan. Hal ini sejalan dengan ungkapan Aristoteles, bahwa karakter erat kaitannya dengan "habit" atau kebiasaan yang terus menerus dipraktikan dan diamalkan. Lebih lanjut masih dari E. Mulyasa mengemukakan Megawangi pencetus pendidikan karakter di Indonesia telah menyusun 9 pilar karakter mulia yang selayaknya dijadikan acuan dalam pendidikan karakter, baik di sekolah maupun diluar sekolah, yaitu sebagai berikut:

1. Cinta Allah dan kebenaran

2. Tanggung jawab, disiplin dan mandiri

3. Amanah

4. Hormat dan santun

5. Kasih sayang, peduli dan kerja sama

6. Percaya diri, kreatif, dan pantang menyerah

7. Adil dan berjiwa kepemimpinan

8. Baik dan rendah diri

9. Toleran dan cinta damai.

Dalam perspektif Islam pendidikan karakter secara teoritik sebenarnya telah ada sejak Islam diturunkan ke dunia, seiring dengan diutusnya Nabi Muhammad SAW untuk memperbaiki atau menyempurnakan akhlak (karakter) manusia. Ajaran Islam sendiri mengandung sistematika ajaran yang tidak hanya menekankan pada aspek keimanan, ibadah dan mu'amalah, tetapi juga akhlak. Pengamalan ajaran Islam secara utuh (kaffah) merupakan model karakter seorang muslim, bahkan dipersonifikasikan dengan model karakter Nabi Muhammad SAW, yang memiliki sifat Shidiq, Tabligh, Amanah, Fathonah (STAF).

Pendidikan Karakter sebenarnya telah dilaksanakan jauh sebelum Indonesia merdeka. Ki Hajar Dewantoro sebagai Pahlawan Pendidikan Nasional memiliki pandangan tentang pendidikan karakter sebagai asas Taman Siswa 1922. Dalam asas Taman Siswa tersebut Dewantara ingin mendidik menusia Indonesia secara utuh (kaffah), yang hidup mandiri, efektif, efisien, produktif dan akuntabel. (E.Mulyasa : 2012).

\section{Implementasi Pendidikan Karakter}

Pendidikan karakter pada tingkat satuan pendidikan menekankan pada keteladanan, penciptaan lingkungan dan pembisaan melalui berbagai tugas 
keilmuan dan kegiatan kondusif. Dengan demikian apa yang dilihat, didengar, dirasakan dan dikerjakan oleh peserta didik dapat membentuk karakter mereka. Selain menjadikan keteladanan dan pembiasaan sebagai metode pendidikan utama, penciptaan iklim dan budaya serta lingkungan yang kondusif juga sangat penting, dan turut membentuk karakter peserta didik.Penciptaan lingkungan yang kondusif dapat dilakukan melalui berbagai variasi metode sebagai berikut: (1) penugasan. (2) pembisaan. (3) pelatihan. (4) pembelajaran. (5) pengarahan dan. (6) keteladan. (E.Mulyasa; 2012)

Pendidikan karakter dapat diintegrasikan dalam seluruh pembelajaran pada setiap bidang studi yang terdapat dalam kurikulum. Materi pembelajaran yang berkaitan dengan norma atau nilai nilai pada setiap bidang perlu dikembangkan, dieksplisitkan, dan dihubungkan dengan konteks kehidupan sehari hari. Dengan demikian pendidikan nilai dan pembentukan karakter tidak hanya dilakukan pada tataran kognitif, tetapi menyentuh internalisasi, dan pengamalan nyata dalam kehidupan sehari hari.

Beberapa negara yang telah menerapkan pendidikan karakter sejak pendidikan dasar diantaranya Amerika Serikat, Jepang, Cina dan Korea. Hasil penelitian di Negara Negara ini menyatakan bahwa implementasi pendidikan karakter yang tersusun secara sistematis berdampak positif pada pencapaian akademis. (Jamal Ma'mur Asmani: 2012)

\section{Peran Guru dalam Pendidikan Karakter}

Guru merupakan sosok yang menjadi idola bagi anak didik. Keberadaannya sebagai jantung pendidikan tidak bisa dipungkiri. Baik atau buruknya pendidikan sangat tergantung pada sosok yang satu ini. Menurut Mulyasa pada Jamal Makmur Asmuni (2012) fungsi guru bersifat multi fungsi. Ia tidak hanya sebagai pendidik, tapi juga sebagai pengajar, pembimbing, pelatih, penasihat, pembaru, mode, teladan, pribadi, peneliti, pendorong kreativitas, pembangkit pandangan, pekerja rutin, pemindah kemah, pembawa cerita, aktor, emancipator, evaluator, pengawet, dan kulminator.

Seorang guru tidak hanya mengajar di dalam kelas, tetapi juga harus mampu menjadi katalisator, motivator, dan dinamisator pembangunan di tempat tinggalnya (labschool-unj.sch.id, yang diakses pada 6 Juni 2011). Pada PP Nomor 19 Tahun 2005 tentang Standar Nasional Pendidikan dinyatakan dalam Pasal 28 Ayat (3) bahwa: kompetensi sebagai agen pembelajaran pada jenjang pendidikan dasar dan menengah serta pendidikan anak usia dini meliputi: 1 . Kompetensi pedagogik; 2. Kompetensi kepribadian; 3. Kompetensi sosial; 4. Kompetensi profesional. Thomas Lickona, 1991 pada Darmiyati (2009:58) menyatakan bahwa guru dalam mengajar di kelas harus berfungsi sebagai pengasuh, model (pemberi teladan), dan mentor. Sebagai pengasuh guru, guru harus bisa mencintai dan menghargai murid murid, menolong mereka agar berhasil di sekolah, mengembangkan kesadaran akan harga diri mereka, dan memperlakukan murid muridnya secara bermoral sehingga mereka dapat mengalami apa yang dimaksud dengan moralitas. Guru juga harus menjadi model atau teladan sebagai orang yang beretika, yang menunjukkan dalam perilakunya rasa hormat dan tanggung jawab yang tinggi baik di dalam maupun diluar kelas.Guru juga dapat memberi teladan 
dengan memberikan perhatian pada moralitas dan melakukan penalaran moral melalui reaksi reaksinya terhadap kejadian kejadian yang secara moral bermakna dalam kehidupan sekolah dan kehidupan secara luas. Sebagai mentor, guru menyelenggarakan pembelajaran dan bimbingan melalui penjelasan, diskusi kelas, bercerita, pemberian dorongan, dan memberikan respon yang berupa koreksi jika murid murid melukai perasaan teman teman mereka atau perasaan guru.

Dinas Pendidikan Provinsi Jawa Barat UPTD Balai Pelatihan Guru mengemukakan, sebagai berikut:

\begin{tabular}{|c|l|}
\hline Tugas & \multicolumn{1}{|c|}{ Peran dalam Pembelajaran } \\
\hline Pertama & $\begin{array}{l}\text { Analisis dan pengembang kurikulum. Pada konteks ini, aktivitas yang } \\
\text { dilakukan adalah menganalisis isi kurikulum dan mengembangkannya } \\
\text { menjadi suatu perangkat yang fokus kearah implementasi didepan } \\
\text { kelas. } \\
\text { Kedua } \\
\text { Analisis klinis potensi siswa. Pada konteks ini, aktivitas yang } \\
\text { dilakukan adalah mengidentifikasi dan mengembangkan potensi fisik } \\
\text { dan psikologis siswa yang menjadi tanggung jawabnya melalui } \\
\text { pelayanan pembimbingan, pembelajaran dan pelatihan. } \\
\text { Ketiga } \\
\text { Manajer kelas, dalam konteks ini aktivitas yang dilakukan adalah, } \\
\text { merencanakan, melaksanakan, dan mengevaluasi pembimbingan, } \\
\text { pembelajaran dan pelatihan. } \\
\text { Fasilitator, yaitu melakukan tindakan memfasilitasi siswa, hal ini } \\
\text { fokus pada penyiapan perangkat dan sumber sumber belajar di } \\
\text { sekolah/madrasah. }\end{array}$ \\
\hline
\end{tabular}

Sumber: Dinas Pendidikan Provinsi Jawa Barat UPTD Balai Pelatihan Guru pada Asmaun Sahlan \& Angga Teguh Prasetio (2012)

\section{E. Taman Kanak-kanak sebagai Pendidikan Formal}

Arti penting pendidikan usia dini, - jenjang pendidikan sebagai upaya pembinaan anak sejak lahir sampai usia enam tahun dilakukan melalui pemberian rangsangan pendidikan untuk membantu pertumbuhan dan perkembangan jasmani rohani agar anak memiliki kesiapan pendidikan lebih lanjut; - penyelenggaraan pendidikan yang dititikberatkan pada peletakan dasar ke arah pertumbuhan dan perkembangan fisik (koordinasi motorik halus \& kasar), kecerdasan, (daya pikir, daya cipta, kecerdasan emosi spiritual sosio-emosional (sikap dan perilaku serta agama);

Pendidikan anak usia dini dalam hal ini hanya berfungsi sebatas membantu dan mengarahkan proses tumbuh kembang anak agar lebih terarah dan terpadu, pendidikan anak usia dini secara khusus bukan bertujuan untuk memberi anak pengetahuan kognitif (kecerdasan intelek) tetapi mempersiapkan mental dan fisik anak untuk mengenal dunia sekitarnya secara lebih adaptive (bersahabat). Sifat pendidikannya lebih familier (kekeluargaan), komunikatif (menyenangkan) dan paling utama lebih persuasive (seruan / ajakan) 
Dalam UU No. 20 Tahun 2003 Pasal 28 dikemukakan tentang Pendidikan Anak Usia Dini isinya sebagai berikut: Pendidikan anak usia dini diselenggarakan sebelum jenjang pendidikan sekolah dasar.

1. Pendidikan anak usia dini dapat diselenggarakan melalui jalur pendidikan formal, non formal dan /atau informal.

2. Pendidikan anak usia dini pada jalur pendidikan formal berbentuk Taman Kanak Kanak (TK) Raudatul Athfal (RA) atau bentuk lain sederajat.

3. Pendidikan anak usia dini pada jalur non formal berbentuk Kelompok Bermain (KB), Taman Penitipan Anak (TPA) atau bentuk lain yang sederajat.

4. Pendidikan anak usia dini pada jalur pendidikan informal berbentuk pendidikan keluarga atau pendidikan yang diselenggarakan olh lingkungan

5. Ketentuan mengenai pendidikan anak usia dini sebagaimana mana dimaksud dalam ayat (1) ,ayat(2), ayat (3) dan ayat (4) diatur lebih lanjut dengan Peraturan Pemerintah

Secara formal (konstitusional) tujuan pendidikan taman kanak-kanak dapat diketahui melalui Undang Undang Sistem Pendidikan Nasional (UU SISDIKNAS). Dalam undang-undang tersebut meskipun pernyataannya menyatu dengan tujuan pendidikan usia dini secara keseluruhan dapat ditarik rumusannya bahwa tujuan pendidikan taman kanak-kanak adalah pemberian rangsangan untuk membentuk pertumbuhan dan perkembangan jasmani dan rohani agar anak memiliki kesiapan dalam memasuki pendidikan lebih lanjut.Rumusan tujuan tersebut diterjemahkan ke dalam Tujuan Kurikulum TK 2004 bahwa:

"TK bertujuan membantu anak didik mengembangkan berbagai potensi baik psikis dan fisik yang meliputi moral dan nilai nilai agama, social emosional, kognitif, bahasa, fisik/ motorik, kemandirian, dan seni untuk siap memasuki pendidikan dasar”.

Selanjutnya dalam Kurikulum TK 2004 tersebut dijabarkan sejumlah fungsi TK sehingga dapat mempermudah para pelaksana / penyelenggara menerjemahkannya ke dalam praktik pendidikan pada level tersebut. Fungsi fungsi yang dimaksud adalah: (1) TK berfungsi mengenalkan peraturan dan menanamkan disiplin pada anak, (2) TK berfungsi mengenalkan anak dengan dunia sekitar, (3) TK berfungsi menumbuhkan sikap dan perilaku yang baik, (4) TK berfungsi mengembangkan kemampuan berkomunikasi dan bersosialisasi, (5) TK berfungsi mengembangkan keterampilan, kreativitas dan kemampuan yang dimiliki anak, serta (6) TK berfungsi menyiapkan anak untuk memasuki pendidikan dasar.

Sebagai lembaga formil Taman Kanak-kanak mempunyai prinsip prinsip dalam kegiatan pembelajaran, prinsip pembelajaran di taman kanak-kanak tersebut, meliputi:

1. Memperkenalkan Dunia dengan Seni dan Keindahan;

2. Prinsip Bermain Sambil Belajar dan Belajar Seraya Bermain;

3. Prinsip Pembelajaran yang Berorientasi pada Dasar Dasar Perkembangan Anak;

4. Prinsip Pendidikan yang Berorientasi pada Kebutuhan Anak;

5. Prinsip Pendekatan Tematik;

6. Prinsip Pendekatan Kreatif dan Inovatif dan; 
7. Prinsip Lingkungan Kondusif;

8. Prinsip Mengembangkan Kecakapan Hidup.

Aspek Aspek Perkembangan di Taman Kanak-kanak dapat diuraikan sebagai berikut.

1. Perkembangan motorik

2. Perkembangan kognitif

3. Perkembangan bahasa

4. Perkembangan sosial emosional dan

5. Perkembangan moral

Anak /siswa melalui pendidikan formal taman kanak-kanak mempunyai kesempatan pengembangan kemampuan kecerdasan hal ini sesuai yang tersirat pada Direktorat Jenderal Pendidikan Luar Sekolah dan Pemuda Departemen Pendidikan Nasional (2002), sebagai berikut

1. kecerdasan linguistik/ linguistic intelligence

2. kecerdasan logika matematika/ logico mathematical

3. kecerdasan visual - spasial /visual- spasial intelligence

4. kecerdesan musikal / musical rhytmmic intelligence,

5. kecerdasan kinestetik/bodily/kinesthetic intelligence

6. kecerdasan naturalis / naturalist intelligence

7. kecerdasan interpersonal / interpersonal intelligence,

8. kecerdasan intrapersonal / intra personal intelligence

9. kecerdasan kinestetik/bodily/kinesthetic intelligence

Dari pengembangan kemampuan kecerdasan tersebut penulis mencoba menjelaskan beberapa pengembangan kemampuan kecerdasan tersebut, hubungannya dengan nilai nilai moral, sebagai berikut:

1. Kecerdasan linguistik/ linguistic intelligence, yang dapat berkembang bila dirangsang diantaranya melalui berbicara, dalam hal ini guru menekankan berbicara yang jujur, dengan siapa berbicara dengan orang tua/guru, sesama teman sebaya dalam hal ini siswa diperkenalkan dengan sopan santun. Demikian pula pada kegiatan lainnya dalam rangka pengembangan kecerdasan linguistik tersebut diantaranya dengan mendengarkan, membaca, menulis, dengan buku, berdiskusi dan bercerita.

2. Kecerdasan logika matematika/ logico mathematical, dapat dirangsang di antaranya, melalui kegiatan menghitung, membedakan bentuk, menganalisis data dan bermain dengan benda benda. Hubungannya dengan nilai nilai moral diantaranya anak dilatih kecerdasannya, kecerdasan kognitif bisa memberikan dampak pada pembentukan karakter yang positif, tumbuh rasa ingin tahu, melatih kemampuan menganalisis, menginterpretasikan, menyimpulkan, dan mempresentasikan.

3. Kecerdasan visual - spasial /visual- spasial intelligence, yaitu kemampuan ruang yang dapat dirangsang melalui bermain bermain balok balok dan bentuk bentuk geometri melengkapi puzzle, menggambar, melukis, menonton film maupun bermain dengan daya khayal (imajinasi). Dengan kegiatan ini anak memiliki kemampuan menguasai benda dalam ruang dan visualisasi rafis, kemampuan kerja sama, cekatan 
4. Kecerdesan musikal / musical rhytmmic intelligence, yang dirangsang melalui irama, nada, birama, berbagai bunyi dan bertepuk tangan. Hubungannya dengan nilai moral diantaranya berimajinasi,

5. Kecerdasan kinestetik /bodily/kinesthetic intelligence, yang dapat dirangsang melalui gerakan, tarian, olah raga dan terutama gerakan tubuh.

6. Kecerdasan naturalis / naturalist intelligence, yaitu mencintai alam. Dapat dirangsang melalui pengamatan lingkungan, bercocok tanam, memelihara binatang, termasuk mengamati fenomena alam seperti hujan, angin, banjir, pelangi, siang malam, panas, dingin, bulan matahari.

7. Kecerdasan interpersonal / interpersonal intelligence, yaitu kemampuan untuk melakukan hubungan antar manusia (berkawan) Dalam hal ini anak memiliki kemampuan memahami perasaan, suasana hati, keinginan dan temperamen orang lain.

8. Kecerdasan intrapersonal / intra personal intelligence, yaitu kemampuan memahami diri sendiri, memiliki kecenderungan untuk memiliki konsep diri yang positif, artinya anak tersebut mengenal kelebihan dan kekurangan dirinya. Ia menyadari bahwa setiap orang memiliki kelebihan dan kekurangan. Demikian dengan dirinya. Gardner salah seorang doctor bidang psikologi dari Harvard University pada Zainal Aqib, 2011: 67 berpendapat bahwa kecerdasan intrapersonal adalah kemampuan seseorang untuk mengenal dirinya sendiri.

9. Kecerdasan spiritual / kecerdasan spiritual/ spiritual intelligence, yaitu kemampuan mengenal dan mencintai ciptaan Tuhan. Dalam hal ini anak mengenal kejadian alam atau diperkenalkan dengan nilai nilai moral dan agama.

\section{F. Pendidikan Karakter pada Taman Kanak Kanak.}

Subjudul tersebut di atas menekankan pendidikan karakter dapat dilaksanakan pada setiap jenjang pendidikan, termasuk pada jenjang pendidikan Taman Kanak-kanak. Anak/ siswa taman kanak-kanak tersebut secara psikologis sudah memiliki kecerdasan dalam hal ini penulis mengutip kajian dari buku dari pendapat Prof. Dr. Howars Gardner psiolog dari Harvard University pada (Zainal Aqib, 2011: 57) bahwa " setiap orang atau setiap anak terlahir dengan memiliki delapan macam kecerdasan, hanya saja akan berbeda urutannya masing masing anak ”. Ada 8 area kecerdasan yaitu sebagai berikut:

1. Cerdas bahasa (verbal linguistical)

2. Cerdas matematis (logical mathematical)

3. Cerdas visual (visual spatial)

4. Cerdas olah tubuh (bodily)

5. Cerdas musik (musical)

6. Cerdas empati (interpesonil)

7. Cerdas paham diri (intrapersonal)

8. Cerdas alam (natural)

Dengan demikian upaya taman kanak-kanak atas pengembangan kemampuan kecerdasan seperti telah diulas pada bagian sebelumnya, selama ini sudah berjalan 
dengan baik. Hanya saja pencapaiannya dipengaruhi oleh karakter dari masingmasing anak .

Pendidikan karakter di Taman Kanak-kanak merupakan kelanjutan dari pendidikan karakter yang diselenggarakan di dalam keluarga. Pendidikan karakter pada Taman Kanak-kanak dapat dilakukan dengan cara pembisaan yang tidak tertulis namun dilangsungkan secara konsisten. Hal ini berarti kehidupan anak/ siswa dijiwai oleh internalisasi nilai nilai pendidikan karakter. Taman Kanakkanak dapat memainkan fungsi menggali dan menguatkan potensi, minat dan bakat yang dimiliki anak/siswa. Apalagi dalam kegiatan belajar mengajar di Taman Kanak-kanak pengembangan siswa diorientasikan kepada pengembangan dan pengeksplorasian potensinya. Dalam hal ini wawasan pendidikan karakter sudah tertanam mulai dalam keluarga, taman kanak-kanak dan akan berlanjut pada jenjang pendidikan selanjutnya.

Kegiatan pembelajaran sehari hari di Taman Kanak-kanak dalam rangka pengembangan kemampuan kecerdasan yang tentu saja disesuaikan dengan prinsip prinsip pembelajarannya, serta nilai nilai yang dikembangkan dalam rangka pendidikan karakter. Implementasi pendidikan karakter pada Taman Kanak-kanak tersebut gambarannya sebagai berikut, sesuai yang tercantum dalam Puskur Kemdiknas pada Asmaun Sahlan \& Angga Teguh Prastyo (2012)

\section{Gambaran Implementasi Pendidikan Karakter Setiap Hari di TK}

\begin{tabular}{|c|c|c|}
\hline Waktu & Kegiatan & $\begin{array}{c}\text { Nilai yang } \\
\text { Dikembangkan }\end{array}$ \\
\hline $\begin{array}{l}\text { Pagi } \\
\text { sebelum } \\
\text { kegiatan }\end{array}$ & $\begin{array}{l}\text { Guru bersiap di pintu gerbang untuk } \\
\text { menyambut kedatangan peserta didik dan } \\
\text { mengucapkan salam. Peserta didik masuk } \\
\text { sendiri tanpa ditemani orang tua. }\end{array}$ & $\begin{array}{l}\text { Kemandirian sopan } \\
\text { santun }\end{array}$ \\
\hline $\begin{array}{l}07.25- \\
07.30\end{array}$ & $\begin{array}{l}\text { Sekitar } 5 \text { menit peserta didik dan guru } \\
\text { melakukan kegiatan “ sapu bersih” yaitu } \\
\text { mengumpulkan yang ada di sekolah. } \\
\text { Cuci tangan }\end{array}$ & Kebersihan \\
\hline $\begin{array}{l}7.30 \\
08.30\end{array}$ & $\begin{array}{l}\text { - Hari Senin: Upacara di halaman sekolah } \\
\text { - Hari Selasa, Rabu, Kamis, Jumat: } \\
\text { berkumpul di aula, penekanan untuk nilai } \\
\text { religius seperti iqro/ akhlak mulia/ membaca } \\
\text { ayat ayat pendek. } \\
\text { - Hari Sabtu olahraga/ senam dilapangan. }\end{array}$ & $\begin{array}{l}\text { Kedisiplinan, } \\
\text { religius, } \\
\text { kemandirian. }\end{array}$ \\
\hline $\begin{array}{l}08.00- \\
10.30\end{array}$ & $\begin{array}{l}\text { Kegiatan rutin kelas } \\
\text { - pembukaan } \\
\text { - Inti } \\
\text {-Istirahat/makan (setelah istirahat } \\
\text { sebelum acara makan dilakukan lagi kegiatan } \\
\text { “sapu bersih”. cuci tangan dan masuk kelas } \\
\text { makan bersama) } \\
\text { - penutup }\end{array}$ & $\begin{array}{l}\text { Religius, } \\
\text { kebersihan, } \\
\text { kedisiplinan, } \\
\text { kemandirian. }\end{array}$ \\
\hline
\end{tabular}




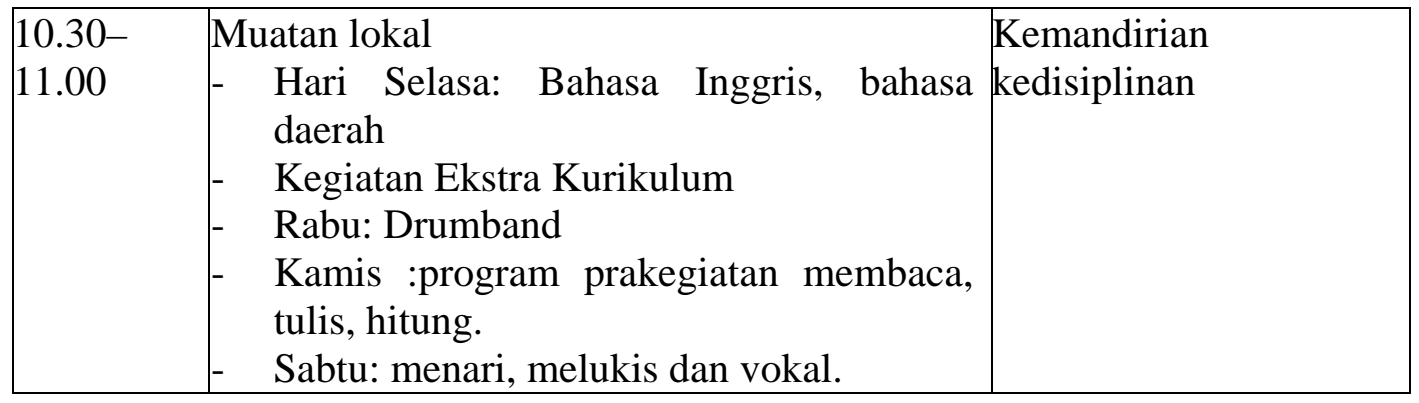

Sumber: Puskur Kemdiknas Pedoman Pelaksanaan Pendidikan Karakter Berdasarkan Pengalaman di Satuian Pendidikan Rintisan

\section{G. PENUTUP}

Demikianlah Taman Kanak-kanak "bertujuan membantu anak didik mengembangkan berbagai potensi baik psikis dan fisik yang meliputi moral dan nilai nilai agama, sosial emosional, kognitif, bahasa, fisik/ motorik, kemandirian, dan seni untuk siap memasuki pendidikan dasar”. Taman Kanak-kanak sebagai bagian pendidikan dasar sebagai jenjang pendidikan formal memiliki fungsi diantaranya, menumbuhkan sikap dan perilaku yang baik, melalui kegiatan pembelajaran yang berprinsip salah satu prinsip diantaranya prinsip bermain sambil belajar dan belajar seraya bermain; dan memiliki aspek aspek pengembangan kemampuan yang beragam serta memiliki upaya upaya pengembangan kemampuan kecerdasan yang begitu bervariasi.

Pendidikan karakter mengantarkan anak /siswa untuk belajar memaknai kearifan. Meski secara fisiologis dan psikologis siswa belum mengerti tentang hal itu, tetapi bila melihat bahwa esensi pendidikan pada hakikatnya peniruan dan pembisaan, kearifan patut dikenalkan sejak dini. (Asmaun Sahlan \& Angga Teguh Prastyo, 2012: 15)

Berdasarkan uraian diatas menurut hemat penulis melalui beberapa kajian buku buku, Pendidikan Karakter dapat dilaksanakan pada Taman Kanak-kanak dalam rangka meningkatkan mutu proses dan hasil pendidikan yang mengarah pada pembentukan karakter dan akhlak mulia peserta didik secara utuh, terpadu, dan seimbang sesuai dengan standar kompetensi lulusan pada setiap jenjang pendidikan.

Melalui pendidikan karakter setidaknya dapat mengantarkan siswa /anak Taman kanak-kanak untuk tumbuh dan berkembang sesuai dengan tujuan pendidikan taman kanak-kanak adalah pemberian rangsangan untuk membentuk pertumbuhan dan perkembangan jasmani dan rohani agar anak memiliki kesiapan dalam memasuki pendidikan lebih lanjut. Pendidikan Karakter pada Taman Kanak-kanak kenapa tidak? Wallahu'alam bisawab

\section{DAFTAR PUSTAKA}

Asmaun Sahlan \& Angga Teguh Prastyo (2012) Desain PembelajaranBerbasis Pendidikan Karakter. Yogyakarta: Ar-Ruzz Media

Darmiyati Zuchdi (2009) Humanisasi Pendidikan. Jakarta: PT Bumi Aksara 
Departemen Pendidikan Nasional (2002) Acuan Menu Pembelajaran pada Pendidikan Anak Usia Dini (Menu Pembelajaran Generik). Jakarta: Depdiknas

Elfindri, dkk (2012) Pendidikan Karakter Kerangka, Metoda, dan Aplikasi Untuk Pendidik dan Profesional. Jakarta: Baduose Media.

Hapidin, dkk (2009) Manajmen Pendidikan TK. Jakarta: Penerbit Universitas Terbuka

Ida Zusnani (2012) Manajemen Pendidikan Berbasis Karakter BangsaJakarta: Tugu Publisher

Jamal Ma'mur Asmani ((2012) Buku Panduan Internalisasi Pendidikan Karakter di Sekolah. Yogyakarta: Diva Press.

Jasa Ungguh Muliawan (2009) Manajemen Play Group \&Taman Kanak Kanak: Bimbingan Mendirikan, Megelola dan Mengembangkan Lembaga Sekolah Anak. Yogyakarta: DIVA Press.

Lembaga Manajemen FEUI (TT) Manajemen Sumberdaya ManusiaKumpulan Essai. Jakarta: LMFEUI, Sucofindo, PT Lautan Berlian Internasional Bank

Mulyasa. E.(2012) Manajemen PAUD. Bandung: PT Remaja ROSDA Karya

Mulyasa. E. (2012) Manajemen Pendidikan Karakter. Jakarta:Bumi Aksara.

Peraturan Pemerintah Republik Indonesia Nomor 19 Tahun 2005 tentang Standar Pendidikan Nasional. Jakarta: Sinar Grafika

Qodri Azizy (2002) Pendidikan (Agama) untuk Membangun Etika Sosial (Mendidik Anak Sukses Masa Depan Pandai dan Bermanfaat).Semarang : C.V. Aneka Ilmu

Sunarto dan Ny. B.Agung Hartono (2002) Perkembangan Peserta Didik Jakarta: Diterbitkan Kerjasama Pusat PerbukuanDepartemen Pendidikan dan Kebudayaan \&Rineka Cipta

Suprihatin, dkk. (1993) Pengembangan Sumber Daya Keluarga: Jakarta: BPK GunungMulia

Suyadi (2011) Manajemen PAUD TPA-KB-TK/RA.Yogyakarta: Pustaka Pelajar

Undang-Undang Guru dan Dosen (UU RI NO. 14 TH.2005) Jakarta: Sinar Grafika

Zainal Aqib (2010) Pedoman Teknis PAUD(Pendidikan Anak Usia Dini)Bandung: NuansaAulia.

Zainal Aqib (2011) Pendidikan KarakterMembangun Perilaku Positif Anak Bangsa. Bandung: Yrama Widya. 